\title{
PERENCANAAN BANGUNAN JETTY DARI BAHAN BRONJONG DI MUARA SUNGAI SUNGGA PANTAI JASRI KABUPATEN KARANGASEM
}

\author{
Putu Gede Panji Oka Chandra ${ }^{1)}$, Cok Agung Yujana', dan I Ketut Yasa Bagiarta') \\ 1) Jurusan Teknik Sipil, Universitas Warmadewa, Denpasar, Bali \\ gedeokachandra04@gmail.com
}

\begin{abstract}
Jasri Beach already has a protection structure in the form of a revetment which also functions to withstand wave overtopping. The tides and river discharge at the mouth of the Sungga River in Jasri Beach affect the spread of sediment floating in the water column and at certain times it can settle on the bottom of the water. Thus, the jetty planning at the mouth of the estuary aims to hold the longshore sediment which is pushed by the waves, into the estuary and then settles which can cause flooding at the mouth of the estuary. Based on the analysis of the jetty structure planning at the estuary of the Sungga River using gabion material, it is obtained: the height of the jetty $\left(E l_{j e t t y}\right)=3 \mathrm{~m}$, the weight of the first layer stone $\left(W_{1}\right)=2.486$ tons, the weight of the second layer $\left(W_{2}\right)=0.2486$ tons, the peak width $(B)=2.434 \mathrm{~m}$, thickness of the first layer $\left(t_{1}\right)=2.434 \mathrm{~m}$, thickness of the second layer $\left(t_{2}\right)=1.129 \mathrm{~m}$, thickness of toe protection $\left(t_{\text {toe }}\right)=1.781 \mathrm{~m}$, width of toe protection $\left(B_{\text {toe }}\right)=2.166 \mathrm{~m}$, weight of toe protection stone $\left(W_{\text {toe }}\right)=0.148$ tons, and the estimated of cost construction is IDR 4,106,578,000.00.
\end{abstract}

Keywords: wave, jetty, overtopping, estuary, Sungga

\begin{abstract}
ABSTRAK
Pantai Jasri telah memiliki bangunan pantai berupa revetment yang juga berfungsi untuk menahan terjadinya limpasan gelombang. Pasang surut dan debit sungai di muara Sungai Sungga Pantai Jasri berpengaruh terhadap penyebaran sedimen yang melayang dikolom air dan saat tertentu dapat mengendap di dasar perairan. Dengan demikian, perencanaan jetty pada mulut muara bertujuan untuk menahan sedimen sejajar pantai yang terdorong oleh gelombang, masuk ke muara dan kemudian mengendap yang dapat menyebabkan terjadinya banjir di mulut muara. Berdasarkan analisis perencanaan bangunan jetty di muara Sungai Sungga dengan menggunakan material bronjong diperoleh: tinggi bangunan jetty $\left(E l_{\text {jetty }}\right)=3 \mathrm{~m}$, berat batu lapis pertama $\left(W_{1}\right)=2.486$ ton, berat batu lapis kedua $\left(W_{2}\right)=0.2486$ ton, lebar puncak $(B)=2.434 \mathrm{~m}$, tebal lapis pertama $\left(t_{1}\right)=2.434 \mathrm{~m}$, tebal lapis kedua $\left(t_{2}\right)=1.129 \mathrm{~m}$, tebal pelindung kaki $\left(t_{t o e}\right)=1.781 \mathrm{~m}$, lebar pelindung kaki $\left(B_{\text {toe }}\right)=2.166 \mathrm{~m}$, berat batu pelindung kaki $\left(W_{\text {toe }}\right)=0.148$ ton, dan perkiraan biaya pembangunannya sebesar Rp.4,106,578,000.00.
\end{abstract}

Kata kunci: gelombang, jetty, limpasan, muara, Sungga 


\section{PENDAHULUAN}

Muara merupakan sebuah habitat yang timbul akibat aktifitas manusia dan proses alam berupa kenaikan muka air laut, serangan arus dan gelombang (Eulie, Corbett, \& Walsh, 2018). Proses alam tersebut mengakibatkan terjadinya pengikisan garis pantai dan penumpukan sedimen di muara sungai (Eulie et al., 2018). Pengikisan dan penumpukan sediman menyebabkan terjadinya perubahan alur sungai, sehingga dapat menghambat laju air yang keluar muara. Tiga faktor dominan yang bekerja secara bersamaan dalam proses perubahan alur pada muara sungai adalah gelombang, debit sungai dan pasang surut (Yowono, 1992). Faktor kondisi gelombang memberikan pengaruh yang signifikan pada sungai kecil, sedangkan faktor besarnya debit sungai akan menjadi faktor utama pada sungai besar (Triatmodjo, 1999).

Analisis besarnya pengikisan garis pantai dan penumpukan sedimen pada muara dapat dilakukan dengan pendekatan pemodelan. Analisis pemodelan dapat dilakukan dengan melakukan survey topografi berkala dan pengambilan sampel lumpur bersamaan dengan pengamatan ketinggian air, kekeruhan air dan kecepatan aliran (Azhikodan \&
Yokoyama, 2021). Analisis dengan menggunakan data hasil pengamatan langsung tentu memerlukan waktu yang cukup lama dan sumber daya yang cukup besar. Alternatif analisis pengikisan garis pantai dan penumpukan sedimen dapat juga dilakukan dengan menggunakan data pemodelan dan penginderaan jauh (Cui \& Li, 2011; Aryastana, Eryani, \& Candrayana, 2016; Aryastana, Ardantha, \& Agustini, 2017; Aryastana, Ardantha, Nugraha, \& Candrayana, 2017; Aryastana, Ardantha, \& Candrayana, 2018; Aryastana, Ardantha, \& Rahadiani, 2018; Ardantha, Aryastana, Rahadiani, \& Candrayana, 2019). Data hasil analisis pemodelan besarnya pengikisan garis pantai dan penumpukan sedimen ini merupakan data dasar dalam penanganan pengamanan kawasan muara sungai dan sekitarnya.

Muara Sungai Sungga yang bermuara di Pantai Jasri, Kabupaten Karangasem. Laju erosi pantai yang terjadi di kawasan Pantai Jasri adalah $4.48 \mathrm{~m} /$ tahun berdasarkan data citra satelit (Aryastana, Ardantha, Rahadiani, \& Candrayana, 2018). Untuk menangani erosi tersebut Pantai Jasri telah memiliki bangunan pantai berupa revetment yang berfungsi untuk menahan terjadinya limpasan gelombang. Besarnya debit sungai dan pasang surut memberi pengaruh terhadap 
penyebaran sedimentasi yang melayang di kolom air dan musim tertentu dapat mengendap di dasar perairan.

Pengendapan ini dapat mengakibatkan adanya pembelokan arah alur sungai. Untuk mengatasinya, maka diperlukan adanya perencanaan jetty pada mulut muara. Perencanaan ini diharapkan mampu menyelesaikan permasalahan perubahan garis pantai dan sedimentasi pada mulut muara. Beberapa perencanaan jetty pada kawasan muara dalam rangka mengatasi permasalahan erosi dan sedimentasi di Provinsi Bali antara lain di muara Sungai Melangit Kabupaten Klungkung (Suryawan, Eryani, \& Rahadiani, 2019), muara Sungai Pangi Kabupaten Badung (Werdi \& Eryani, 2020). Perencanaan saat ini akan menggunakan material berupa bronjong. Bronjong merupakan kombinasi kawat galvanis yang dianyam dengan dimensi dan bentuk tertentu yang kemudian dimasukkan bantu dengan dimensi tertentu dan ditumpuk dengan formasi tertentu. Penggunaan bronjong diharapkan mampu mengatasi permasalahan erosi dan sedimentasi yang terjadi di mulut muara.

\section{KAJIAN PUSTAKA}

\subsection{Kecepatan Angin}

Kecepatan angin merupakan komponen utama dalam analisis peramalan gelombang. Kecepatan angin yang digunakan adalah kecepatan pada ketinggian 10 meter, yaitu seperti persamaan berikut ini (Triatmodjo, 1999):

$$
\mathrm{U}_{10}=\mathrm{U}_{(\mathrm{y})} \mathrm{x}\left(\frac{10}{15}\right)^{1 / 7}
$$

Dimana $\mathrm{U}_{10}$ adalah kecepatan angin pada ketinggian 10 meter, dan $\mathrm{U}_{(\mathrm{y})}$ adalah kecepatan angin pada stasiun. Kecepatan angin dihitung akibat adanya koreksi stabilitas dan lokasi dihitung dengan menggunakan persamaan 2 dan Gambar 1.

$$
\mathrm{R}_{\mathrm{L}}=\mathrm{UW}_{\mathrm{W}} / \mathrm{U}_{\mathrm{L}}
$$

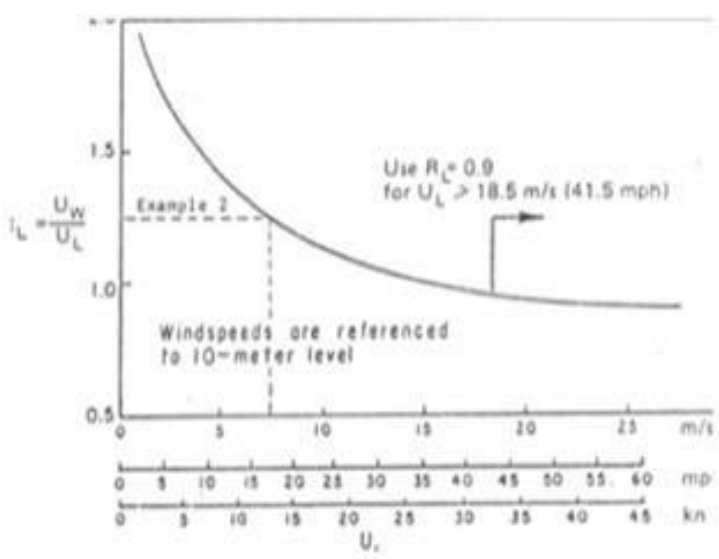

Gambar 1. Kecepatan Angin

(Sumber: Triatmodjo, 1999)

Faktor tegangan angin $\left(\mathrm{U}_{\mathrm{A}}\right)$ diperlukan untuk mengkoreksi kecepatan angin dengan menggunakan persamaan berikut (Triatmodjo, 1999):

$$
\mathrm{U}_{\mathrm{A}}=0.71 \cdot \mathrm{Uw}^{1.23}
$$

\subsection{Panjang Fetch}

Panjang efektif suatu angin berhembus dengan arah dan kecepatan 
yang tetap disebut panjang fetch efektif $\left(F_{\text {eff }}\right)$, dihitung dengan (Yowono, 1992):

$$
\mathrm{F}_{\mathrm{eff}}=\frac{\sum \mathrm{X}_{\mathrm{i}} \cdot \operatorname{Cos} \alpha}{\sum \operatorname{Cos} \alpha}
$$

\subsection{Gelombang Kala Ulang}

Tahap awal dalam menentukan gelombang kala ulang adalah dengan menentukan tinggi gelombang signifikan $\left(\mathrm{H}_{\mathrm{s}}\right)$ dan periode gelombang signifikan $\left(\mathrm{T}_{\mathrm{S}}\right)$, yaitu dengan persamaan $\left.\mathrm{c}\right)$ :

$$
\begin{gathered}
\mathrm{H}_{\mathrm{s}}=\frac{0.0016 \times \sqrt{\frac{\mathrm{g} \cdot \mathrm{F}_{\text {eff }}}{\mathrm{U}_{\mathrm{A}}^{2}}} \times \mathrm{U}_{\mathrm{A}}^{2}}{\mathrm{~g}} \ldots \ldots \ldots \ldots \ldots . . . \\
\mathrm{T}_{\mathrm{S}}=\frac{0.2857 \times\left(\frac{\mathrm{g} \cdot \mathrm{F}_{\mathrm{eff}}}{\mathrm{U}_{\mathrm{A}}{ }^{2}}\right)^{\frac{1}{3}} \times \mathrm{U}_{\mathrm{A}}}{\mathrm{g}} \ldots \ldots \ldots \ldots \ldots . .
\end{gathered}
$$

Tinggi gelombang $\left(\mathrm{H}_{25}\right)$ dan periode $\left(\mathrm{T}_{25}\right)$ kala ulang untuk 25 tahun dihitung dengan menggunakan persamaan (Yowono, 1992):

$$
\begin{aligned}
& \overline{\mathrm{H}}=\frac{\sum \mathrm{H}_{\mathrm{s}}}{\sum \mathrm{N}} . \\
& \sigma \mathrm{H}=\sqrt{\frac{\sum(\mathrm{H}-\overline{\mathrm{H}})^{2}}{\mathrm{~N}-1}} . \\
& \mathrm{H}_{25}=\overline{\mathrm{H}}+\frac{\sigma \mathrm{H}}{0.94}(3.1985-0.495) \ldots . \\
& \mathrm{T}_{25}=0.33 \times \sqrt{\frac{\mathrm{H}_{25}}{0.0056}} .
\end{aligned}
$$

Analisis perhitungan panjang gelombang $\left(\mathrm{L}_{0}\right)$, cepat rambat gelombang $\left(\mathrm{C}_{0}\right)$ dan tinggi gelombang rencana di laut dalam $\left(\mathrm{H}_{0}\right)$ dihitung dengan persamaan berikut (Triatmodjo, 1999):

$$
\mathrm{L}_{0}=1.56 \cdot \mathrm{T}_{25}{ }^{2}
$$

$$
\begin{aligned}
& \mathrm{C}_{0}=1.56 \cdot \mathrm{T}_{25} \ldots \ldots \\
& \mathrm{H}_{0}=\mathrm{Ks} \cdot \mathrm{Kr} \cdot \mathrm{H}_{25}
\end{aligned}
$$

\subsection{Gelombang Pecah}

Gelombang dari laut dalam akan pecah pada kedalaman tertentu ketika menuju pantai. Tinggi gelombang pecah $\left(\mathrm{H}_{\mathrm{b}}\right)$ ditentukan dengan menggunakan persamaan 14 dan bantuan Gambar 2 berikut ini (Triatmodjo, 1999):

$$
\frac{\mathrm{H}_{\mathrm{b}}}{\mathrm{H}_{0}^{\prime}}=\frac{1}{3.33\left(\mathrm{H}_{0} / \mathrm{L}_{0}\right) \frac{1}{3}}
$$

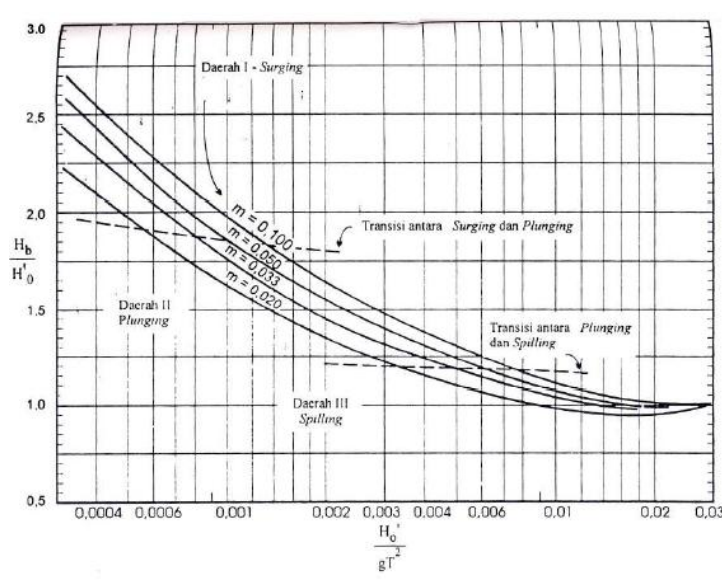

\section{Gambar 2. Hubungan Kemiringan dan Tinggi Gelombang Pecah (Sumber: Triatmodjo, 1999)}

Kedalaman air di mana gelombang akan pecah diberikan oleh rumus berikut (Triatmodjo, 1999):

$$
\begin{aligned}
& \frac{\mathrm{d}_{\mathrm{b}}}{\mathrm{H}_{\mathrm{b}}}=\frac{1}{\mathrm{~b}-\left(\mathrm{a} \mathrm{H}_{\mathrm{b}} / \mathrm{gT}^{2}\right)} \ldots \ldots . . \\
& \mathrm{a}=43.75\left(1-\mathrm{e}^{-19 \mathrm{~m}}\right) \\
& \mathrm{b}=\frac{1.56}{\left(1+\mathrm{e}^{-19.5 \mathrm{~m}}\right)} \ldots \ldots \ldots \ldots
\end{aligned}
$$




\subsection{Jetty}

Bangunan yang berfungsi menangkap sedimen dan diletakkan tegak lurus pantai biasa disebut dengan jetty (Triatmodjo, 1999). Elevasi puncak $\left(\mathrm{El}_{\text {jetty }}\right)$, berat batu pelindung $(\mathrm{W})$, tebal lapis pelidung ( $\mathrm{t}$ ), dan lebar batu puncak jetty (B) dihitung dengan menggunakan rumus (Yowono, 1992; Triatmodjo, 1999):

$$
\begin{aligned}
& \mathrm{El}_{\text {jetty }}=\mathrm{DWL}+\mathrm{R}_{\mathrm{u}}+\mathrm{F}_{\mathrm{b}} \\
& \mathrm{W}=\frac{\gamma_{\mathrm{r}} \cdot \mathrm{H}^{3}}{\mathrm{KD}\left(\mathrm{S}_{\mathrm{r}}-1\right)^{3} \cot \theta} \\
& \mathrm{t}=\mathrm{nK} \Delta\left(\frac{\mathrm{w}}{\gamma_{\mathrm{r}}}\right)^{\frac{1}{3}} \\
& \mathrm{~N}=\mathrm{A} n \mathrm{~K} \Delta\left(1-\frac{\mathrm{P}}{100}\right)\left(\frac{\gamma_{\mathrm{r}}}{\mathrm{W}}\right)^{\frac{2}{3}} \\
& \mathrm{~B}=\mathrm{nK} \Delta\left(\frac{\mathrm{W}}{\gamma_{\mathrm{r}}}\right)^{\frac{1}{3}}
\end{aligned}
$$

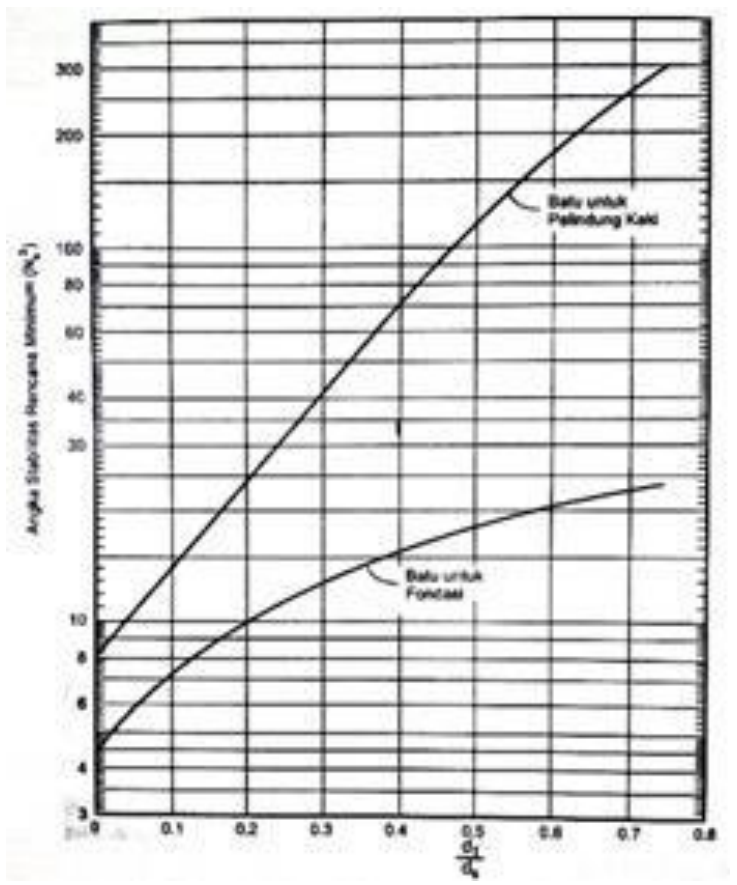

Gambar 3. Angka Stabilitas pada Kaki Pelindung Jetty

(Sumber: Triatmodjo, 1999)

\subsection{Bronjong}

Bronjong umumnya digunakan sebagai bahan struktur pengaman pantai dan sungai. Bronjong merupakan anyaman kawat baja yang berbentuk balok dengan dimensi tertentu yang berisi material batu dengan dimensi tertentu. Bronjong umumnya dipasang diletakkan pada tebing pantai atau tepi sungai untuk menahan longsor tebing atau menahan gerusan air atau gelombang. Standar mutu dan cara uji bronjong dan kawat bronjong harus memenuhi SNI 03-0090-1987, sedangkan standar bahan baku kawat bronjong harus sesuai dengan SNI 03-6154-1999. Batu yang digunakan sebagai pengisi bronjong harus keras, kuat, bersih, tahan lama, berbentuk bulat atau persegi, dengan dimensi antara $15-25 \mathrm{~cm}$, minimal $85 \%$ batu yang digunakan harus memiliki dimensi yang ama atau lebih besar, batu yang digunakan tidak diperbolehkan keluar dari lubang kawat anyaman. (Pattipawaej, Tanamal, Desiani, Dani, \& Pratama, 2013).

\section{METODE PERENCANAAN}

Proses perencanan jetty di muara Sungai Sungga, Kabupaten Karangasem mengikuti flowchart pada Gambar 4. 


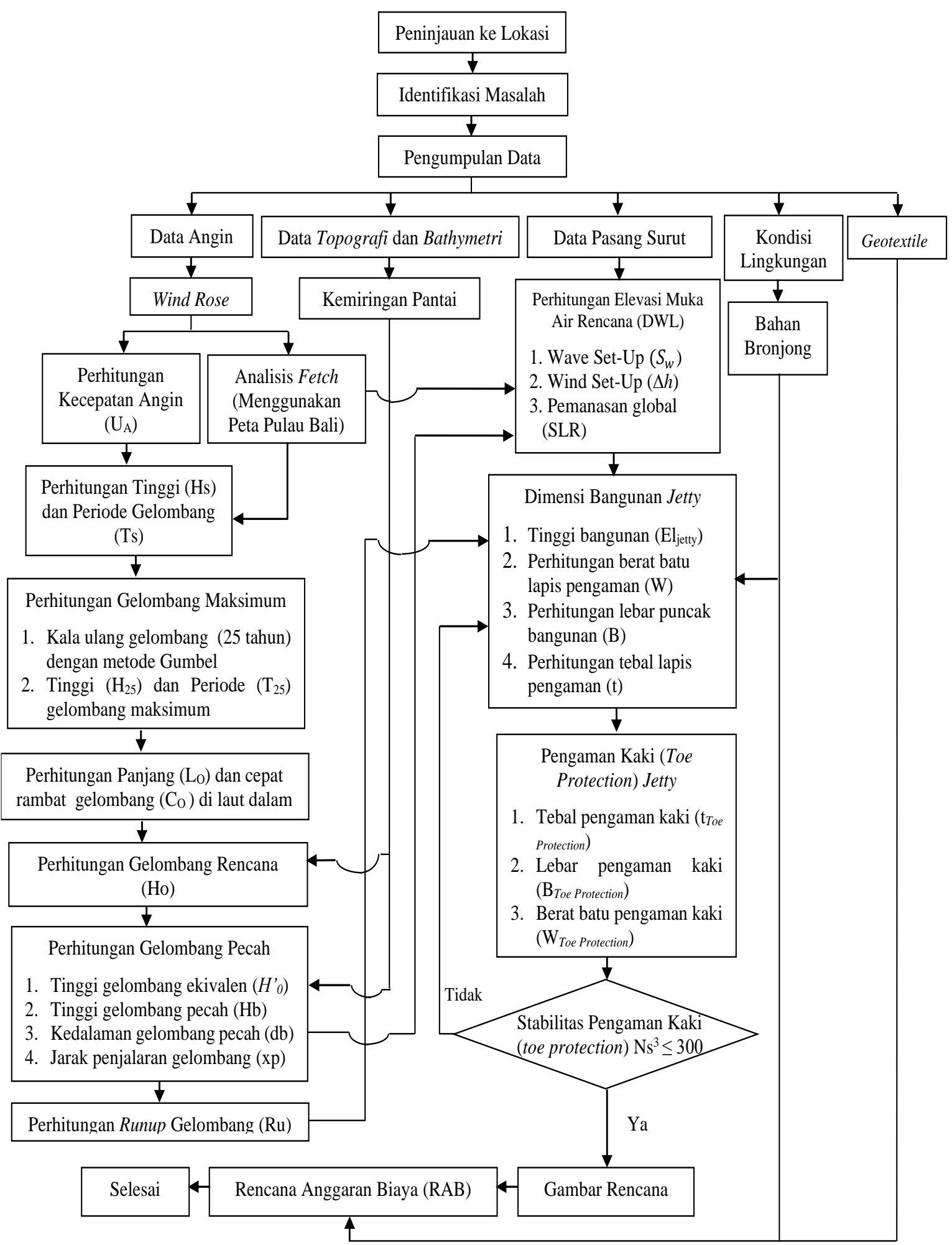

Gambar 4. Alur Perencanaan 


\section{HASIL DAN PEMBAHASAN}

\subsection{Perhitungan Kecepatan dan Arah Angin}

Mawar angin digunakan untuk menggambarkan kecepatan dan arah angin pada area studi dengan menggunakan data angin dari tahun 2012 sampai 2019. Sebaran kecepatan dan arah angin pada daerah studi dapat dilihat pada Gambar 5. Mawar angin menunjukkan bahwa angin dominan bertiup dari arah timur.

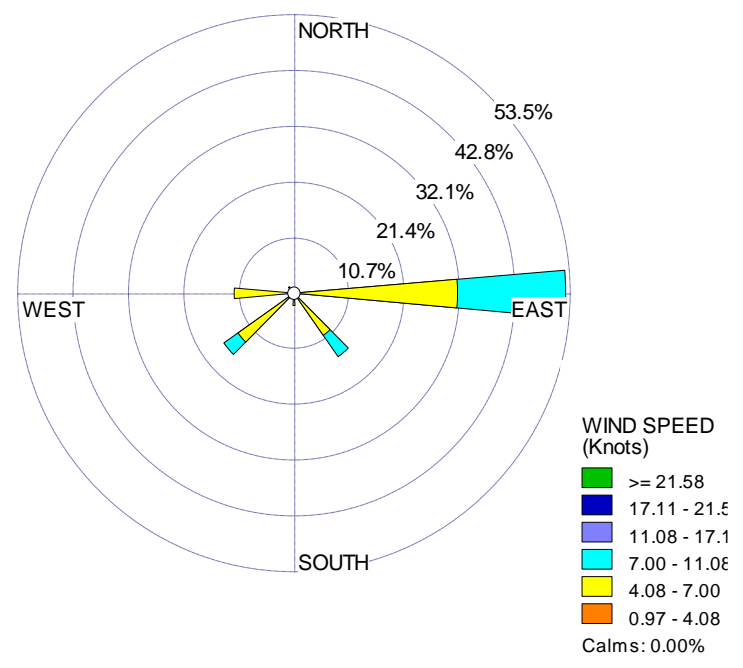

Gambar 5. Mawar Angin di Muara Sungai Sungga Pantai Jasri

Hasil analisis kecepatan angin yang dihitung dengan menggunakan persamaan 1 sampai dengan 3 terdapat pada Tabel 1 . Hasil analisis pada tahun 2012 sampai dengan 2019 menunjukkan bahwa kecepatan maksimum angin pada ketinggian 10 meter adalah 3.880 m/detik, sedangkan koreksi tegangan angin maksimum adalah $6.297 \mathrm{~m} /$ detik.
Tabel 1. Analisis Kondisi Angin pada Daerah Studi

\begin{tabular}{ccccccc}
\hline Tahun & Arah & $\begin{array}{c}\mathrm{U}_{15} \\
(\mathrm{~m} / \mathrm{dt})\end{array}$ & $\begin{array}{c}\mathrm{U}_{10} \\
(\mathrm{~m} / \mathrm{dt})\end{array}$ & $\mathrm{R}_{\mathrm{L}}$ & $\begin{array}{c}\mathrm{U}_{\mathrm{W}} \\
(\mathrm{m} / \mathrm{dt})\end{array}$ & $\begin{array}{c}\mathrm{U}_{\mathrm{A}} \\
(\mathrm{m} / \mathrm{dt})\end{array}$ \\
\hline 2012 & Timur & 4.112 & 3.880 & 1.52 & 5.897 & 6.297 \\
2013 & Timur & 4.112 & 3.880 & 1.52 & 5.897 & 6.297 \\
2014 & Timur & 4.112 & 3.880 & 1.52 & 5.897 & 6.297 \\
2015 & Timur & 3.598 & 3.395 & 1.56 & 5.296 & 5.517 \\
2016 & Timur & 3.598 & 3.395 & 1.56 & 5.296 & 5.517 \\
2017 & Timur & 4.112 & 3.880 & 1.52 & 5.897 & 6.297 \\
2018 & Timur & 4.112 & 3.880 & 1.52 & 5.897 & 6.297 \\
2019 & Timur & 3.598 & 3.395 & 1.56 & 5.296 & 5.517 \\
\hline
\end{tabular}

Hasil analisis panjang fetch untuk setiap ruas di muara Sungai Sungga Pantai jasri yang dihitung berdasarkan Gambar 6 dapat dilihat pada Tabel 2.

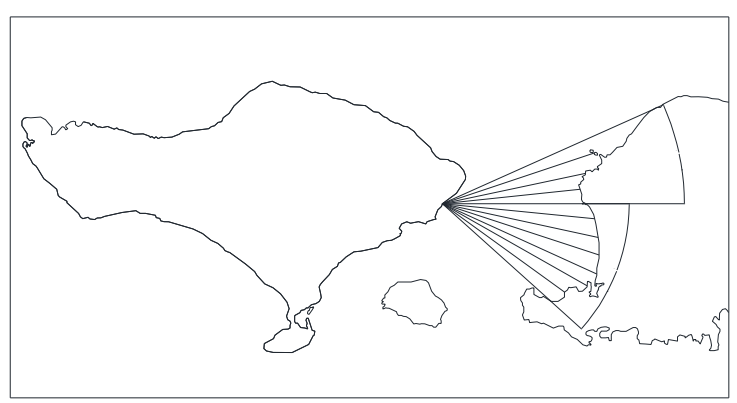

Gambar 6. Analisis Panjang Fetch untuk Setiap Ruas di Muara Sungai Sungga Pantai Jasri

Tabel 2. Analisis Panjang Fetch di Muara Sungai Sungga Pantai Jasri

\begin{tabular}{ccccc}
\hline Arah & Sudut & Cos $\alpha$ & $\mathrm{X}_{\mathrm{i}}(\mathrm{km})$ & $\mathrm{Xi} \cdot \operatorname{Cos} \alpha$ \\
\hline & 42 & 0.743 & 0 & 0 \\
& 36 & 0.809 & 0 & 0 \\
& 30 & 0.866 & 0 & 0 \\
& 24 & 0.914 & 73.60 & 67.270 \\
& 18 & 0.951 & 51.80 & 49.261 \\
& 12 & 0.978 & 48.46 & 47.393 \\
& 6 & 0.995 & 47.39 & 47.153 \\
& 0 & 1 & 46.24 & 46.240 \\
& 6 & 0.995 & 50.93 & 50.675 \\
& 12 & 0.978 & 52.13 & 50.983 \\
& 18 & 0.951 & 53.15 & 50.545 \\
& 24 & 0.914 & 55.22 & 50.471 \\
& 30 & 0.866 & 53.33 & 46.183 \\
& 36 & 0.809 & 47.27 & 38.241 \\
& 42 & 0.743 & 46.34 & 34.431 \\
\hline \multirow{6}{*}{ Total } & 11.094 & & 578.846 \\
\hline
\end{tabular}


Dengan menggunakan persamaan 4 maka diperoleh panjang fetch efektif ( $\left.\mathrm{F}_{\mathrm{eff}}\right)$ adalah 52.17649 kilometer atau 52176.49 meter. Nilai Feff ini akan dijadikan dasar dalam perhitungan selanjutnya.

\subsection{Perhitungan Gelombang Rencana}

Hasil analisis $\mathrm{H}_{\mathrm{s}}$ dan $\mathrm{T}_{\mathrm{s}}$ pada periode tahun 2012-2019 yang dihitung berdasarkan persamaan 5 dan 6 disajikan dalam Tabel 3. Nilai $\mathrm{H}_{\mathrm{s}}$ maksimum adalah 0.735 meter, sedangkan nilai $\mathrm{T}_{\mathrm{s}}$ maksimum adalah 4.302 detik.

Tabel 3. Analisis $H_{s}$ dan $T_{s}$ periode 2012-2019

\begin{tabular}{cccc}
\hline Tahun & $\mathrm{F}_{\text {eff }}(\mathrm{m})$ & $\mathrm{H}_{\mathrm{s}}(\mathrm{m})$ & $\mathrm{T}_{\mathrm{s}}(\mathrm{dt})$ \\
\hline 2012 & 52176.49 & 0.735 & 4.302 \\
2013 & 52176.49 & 0.735 & 4.302 \\
2014 & 52176.49 & 0.735 & 4.302 \\
2015 & 52176.49 & 0.643 & 4.116 \\
2016 & 52176.49 & 0.643 & 4.116 \\
2017 & 52176.49 & 0.735 & 4.302 \\
2018 & 52176.49 & 0.735 & 4.302 \\
2019 & 52176.49 & 0.643 & 4.116 \\
\hline
\end{tabular}

Nilai $\mathrm{H}_{\mathrm{s}}$ pada Tabel 3 digunakan sebagai dasar dalam perhitungan komponen tinggi gelombang pada Tabel 4.

Tabel 4. Analisis Komponen Tinggi Gelombang Rencana

\begin{tabular}{|c|c|c|c|c|}
\hline Tahun & $\mathrm{U}_{\mathrm{A}}(\mathrm{m} / \mathrm{dt})$ & $\mathrm{H}_{\mathrm{s}}(\mathrm{m})$ & $\left(\mathrm{Hs}-\overline{\mathrm{H}_{\mathrm{s}}}\right)$ & $\left(\mathrm{Hs}-\overline{\mathrm{H}_{\mathrm{s}}}\right)^{2}$ \\
\hline 2012 & 6.297 & 0.735 & 0.034 & 0.0012 \\
\hline 2013 & 6.297 & 0.735 & 0.034 & 0.0012 \\
\hline 2014 & 6.297 & 0.735 & 0.034 & 0.0012 \\
\hline 2015 & 5.517 & 0.643 & -0.058 & 0.0034 \\
\hline 2016 & 5.517 & 0.643 & -0.058 & 0.0034 \\
\hline 2017 & 6.297 & 0.735 & 0.034 & 0.0012 \\
\hline 2018 & 6.297 & 0.735 & 0.034 & 0.0012 \\
\hline 2019 & 5.517 & 0.643 & -0.058 & 0.0034 \\
\hline \multicolumn{2}{|c|}{ Total } & 5.604 & & 0.016 \\
\hline
\end{tabular}

Tinggi gelombang rencana $\left(\mathrm{H}_{25}\right)$ dan periode gelombang $\left(\mathrm{T}_{25}\right)$ dengan kala ulang 25 tahun dihitung dengan menggunakan persamaan 8 sampai 10 . Besarnya $\mathrm{H}_{25}$ dan $\mathrm{T}_{25}$ berturut-turut adalah 0.846 meter dan 4.056 detik. Nilai H25 dan T25 ini akan dipergunakan untuk menghitung $\mathrm{L}_{0}, \mathrm{C}_{0}$ dan $\mathrm{H}_{0}$ dengan menggunakan persamaan 11 sampai dengan 13. Hasil perhitungan $\mathrm{L}_{0}, \mathrm{C}_{0}$ dan $\mathrm{H}_{0}$ berturut-turut adalah $25.698 \mathrm{~m}, 6.336$ $\mathrm{m} / \mathrm{dt}$, dan $0.722 \mathrm{~m}$.

\subsection{Perhitungan Gelombang Pecah}

Hasil analisis setiap komponen dalam penentuan gelombang pecah adalah:

1. Tinggi gelombang ekivalen pada kedalaman $2 \mathrm{~m}$ :

$$
\mathrm{H}_{0}{ }^{\prime}=\mathrm{K}_{\mathrm{r}} \times \mathrm{H}_{0}=0.643 \mathrm{~m}
$$

2. Komponen gelombang pecah:

$$
\begin{aligned}
& \frac{\mathrm{H}_{0}^{\prime}}{\mathrm{gT}^{2}}=\frac{0.643 \mathrm{~m}}{9.81 \mathrm{~m} / \mathrm{dt}^{2} \times(4.056 \mathrm{dt})^{2}} \\
& \frac{\mathrm{H}_{0}^{\prime}}{\mathrm{gT}^{2}}=0.00398
\end{aligned}
$$

Nilai komponen gelombang pecah sebesar 0.00398 tersebut kemudian dimasukkan ke dalam Gambar 2, sehingga mendapatkan komponen lainnya seperti pada Gambar 7. Hasil pada Gambar 7 digunakan untuk menghitung tinggi gelombang pecah dengan menggunakan persamaan 14 , dimana diperoleh nilai $\mathrm{Hb}$ adalah $0.6602 \mathrm{~m}$. 


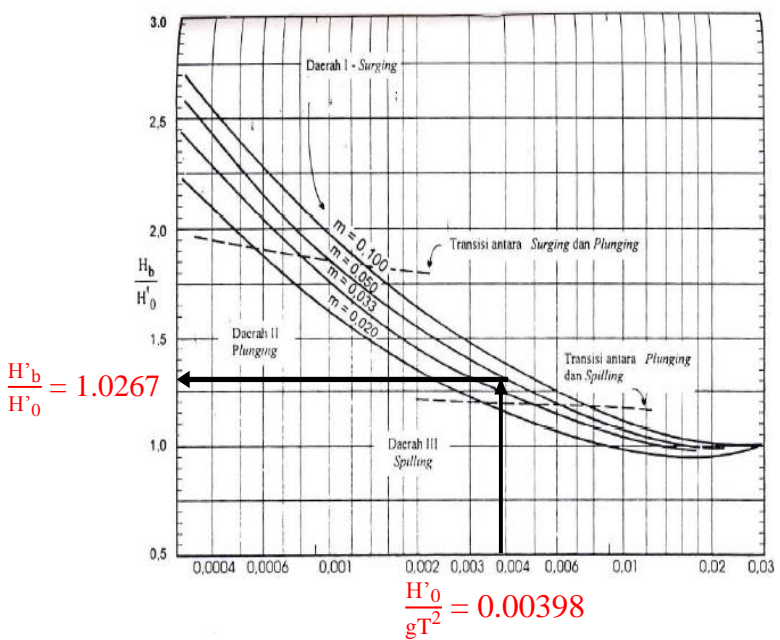

Gambar 7. Perhitungan Komponen Tinggi Gelombang Pecah

Analisis kedalaman gelombang pecah pecah $\left(\mathrm{d}_{\mathrm{b}}\right)$, dimana terlebih dahulu dihitung komponen pendukungnya yaitu:

$$
\begin{aligned}
\frac{\mathrm{H}_{\mathrm{b}}}{\mathrm{gT}^{2}} & =\frac{0.6602 \mathrm{~m}}{9.81 \mathrm{~m} / \mathrm{dt}^{2} \times(4.056 \mathrm{dt})^{2}} \\
\frac{\mathrm{H}_{\mathrm{b}}}{\mathrm{gT}^{2}} & =0.00409
\end{aligned}
$$

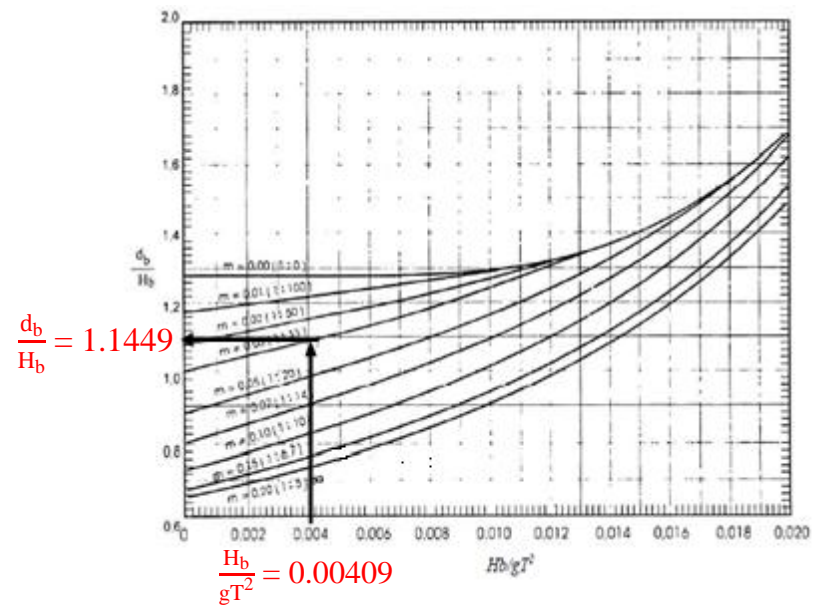

Gambar 8. Hasil Perhitungan Komponen Kedalaman Gelombang Pecah

Hasil komponen sumbu y pada Gambar 8 digunakan untuk menentukan nilai kedalaman gelombang pecah $\left(d_{b}\right)$ dengan menggunakan persamaan 15-17.
Nilai $d_{b}$ diperoleh sebesar $0.6917 \mathrm{~m}$. Nilai $\mathrm{H}_{b}$ dan $\mathrm{d}_{\mathrm{b}}$ ini yang dijadikan dasar dalam meletakkan bangunan jetty dan menentukan dimensi material yang akan digunakan.

\subsection{Perhitungan Elevasi dan Dimensi Bangunan Jetty}

1. Elevasi muka air rencana (DWL):

DWL $=0.90 \mathrm{~m}+0.1028 \mathrm{~m}+$ $0.16184 m+0.23 m$

DWL $=1.395 \mathrm{~m}$

2. Elevasi puncak jetty:

El $_{\text {jetty }}=\mathrm{DWL}+\mathrm{Ru}+$ Tinggi Jagaan

$\mathrm{El}_{\text {jetty }}=3 \mathrm{~m}$

3. Berat batu lapis lindung:

$\mathrm{W}_{1}=\frac{\gamma_{\mathrm{r}} \cdot \mathrm{H}^{3}}{\mathrm{KD}\left(\mathrm{S}_{\mathrm{r}}-1\right)^{3} \cot \theta}$

$\mathrm{W}_{1}=2.486$ ton

$\mathrm{W}_{2}=\frac{1}{10} \times \mathrm{W}$

$\mathrm{W}_{2}=0.2486$ ton

4. Lebar puncak jetty:

$\mathrm{B}=\mathrm{nK} \Delta\left(\frac{\mathrm{W}}{\gamma_{\mathrm{r}}}\right)^{\frac{1}{3}}=2.434 \mathrm{~m}$

5. Tebal lapis lindung:

$\mathrm{t}_{1}=\mathrm{nK} \Delta\left(\frac{\mathrm{W}}{\gamma_{\mathrm{r}}}\right)^{\frac{1}{3}}$

$\mathrm{t}_{1}=2.434 \mathrm{~m}$

$\mathrm{t}_{2}=2 \times 1.02 \times\left(\frac{0.2486}{1.4635}\right)^{1 / 3}$

$\mathrm{t}_{2}=1.129 \mathrm{~m}$ 
6. Tinggi pelindung kaki bangunan:

$\mathrm{t}_{\text {toe }}=1.781 \mathrm{~m}$

7. Lebar pelindung kaki bangunan:

$\mathrm{B}_{\text {toe }}=3 \times 0.722 \mathrm{~m}$

$\mathrm{B}_{\text {toe }}=2.166 \mathrm{~m}$

8. Kontrol stabilitas pelindung kaki bangunan:

$$
\begin{aligned}
\mathrm{d}_{\mathrm{s}} & =2.507 \mathrm{~m} \\
\mathrm{~d}_{1} & =2.507 \mathrm{~m}-1.607 \mathrm{~m} \\
\mathrm{~d}_{1}=0.90 \mathrm{~m} & \mathrm{~d}_{1}=0.359
\end{aligned}
$$

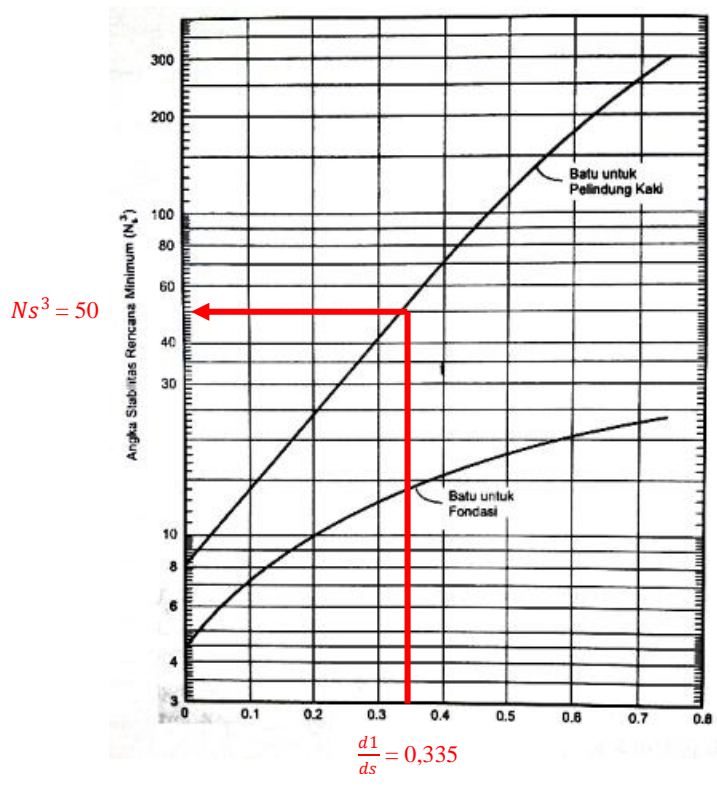

Gambar 9. Analisis Komponen Stabilitas Pelindung Kaki Jetty

Rancangan tata letak dan penampang bangunan jetty di muara Sungai Sungga ditampilkan pada Gambar 10 dan 11. diperoleh nilai $\mathrm{N}_{\mathrm{s}}{ }^{3}$ seperti pada Gambar 9 . Nilai $\mathrm{N}_{\mathrm{s}}{ }^{3}=50 \leq 300$ sehingga bangunan jetty dapat dikatakan aman.

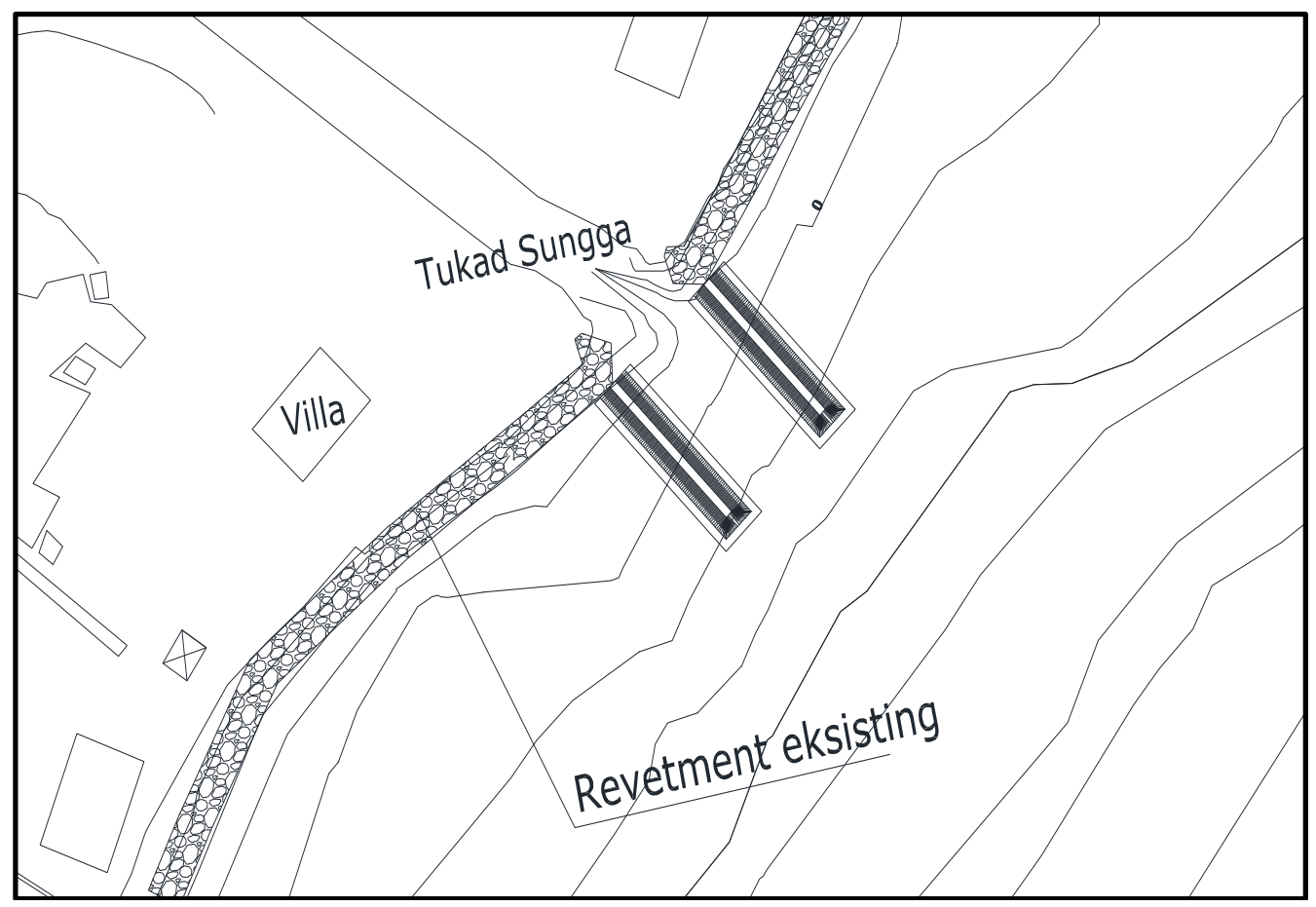

Gambar 10. Denah Penempatan Jetty di Muara Sungai Sungga 


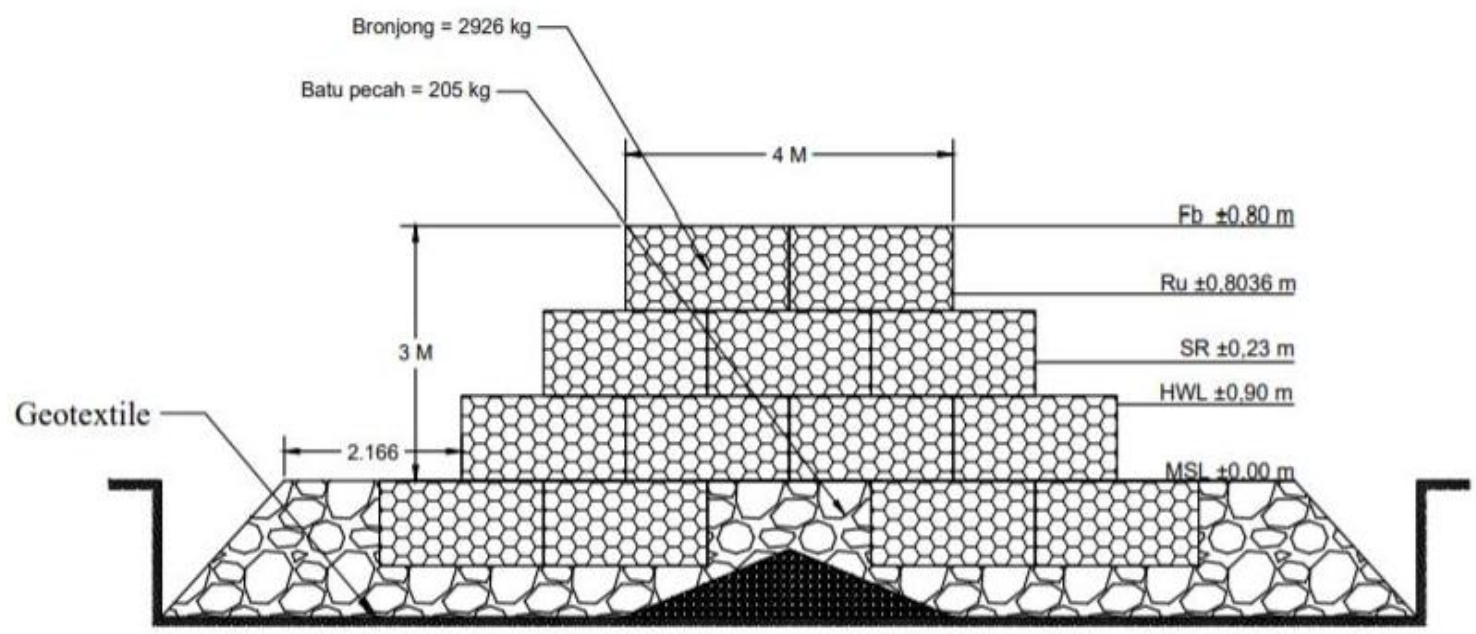

Gambar 11. Potongan Melintang Jetty di Muara Sungai Sungga

Tabel 5. Rincian Perkiraan Biaya Pembangunan Jetty di Muara Sungai sungga

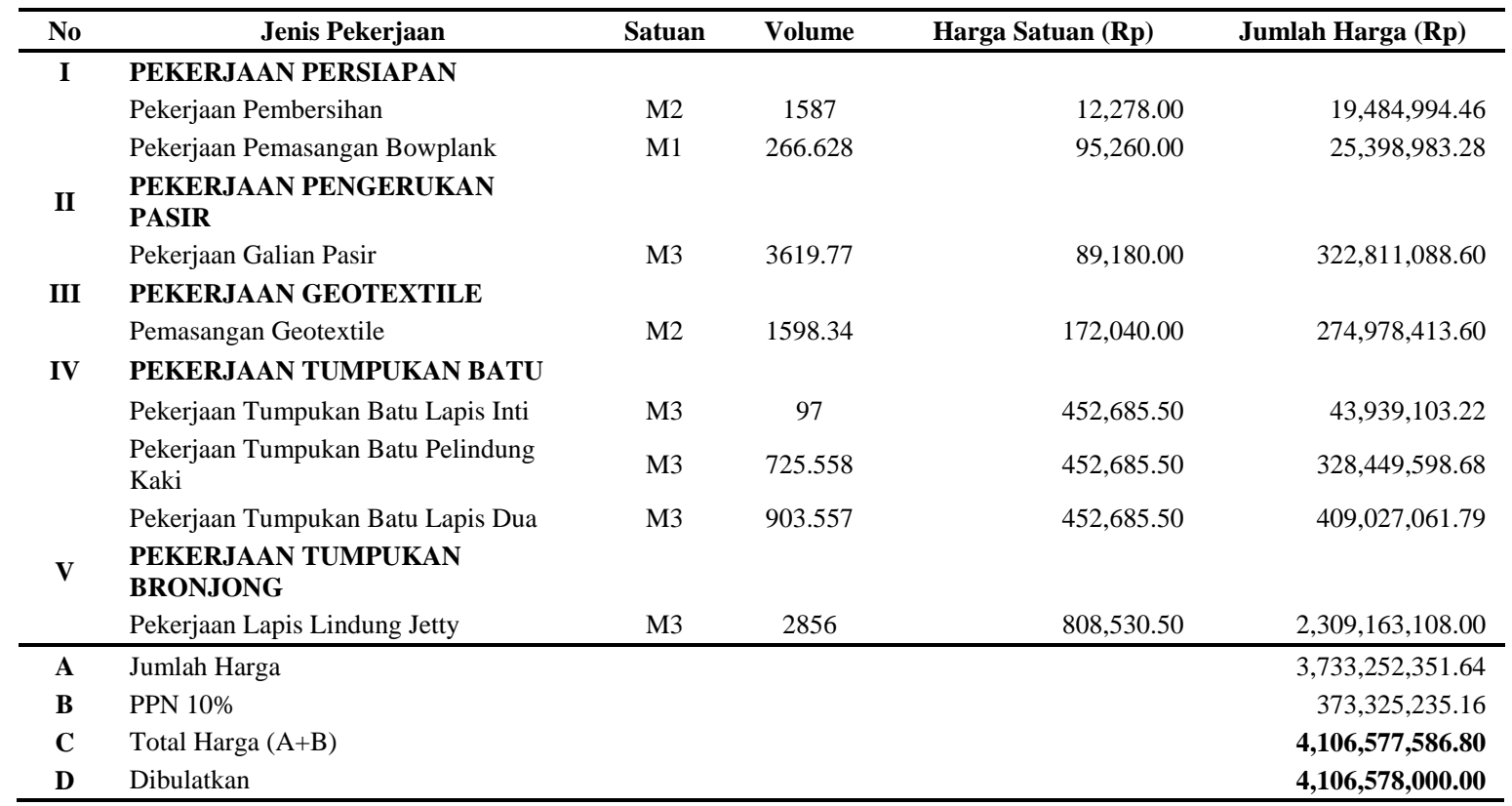

\subsection{Perhitungan Perkiraan Biaya}

Tabel 5 menunjukkan total perkiraan biaya dalam rangka pembangunan jetty di muara Sungai Sungga Pantai Jasri yaitu sebesar Rp.4,106,578,000.00 (Empat Milyar Seratus Enam Juta Lima Ratus Tujuh Puluh Delapan Ribu Rupiah).

\section{SIMPULAN DAN SARAN}

\subsection{Simpulan}

Dari perencanaan jetty dari bahan bronjong pada muara Sungai Sungga diperoleh:

1. Angin dominan berasal dari arah Timur dengan persentase 52.50 $\%$, dengan kecepatan angin terkoreksi $\left(\mathrm{U}_{\mathrm{A}}\right)=6.297 \mathrm{~m} / \mathrm{dt}$. 
2. Tinggi gelombang maksimum untuk periode ulang 25 tahun $\left(\mathrm{H}_{25}\right)$ yaitu 0.846 meter.

3. Periode gelombang maksimum untuk periode ulang 25 tahun ( $\left.\mathrm{T}_{25}\right)$ yaitu 4.056 detik.

4. Tinggi gelombang pecah $\left(\mathrm{H}_{\mathrm{b}}\right)=$ $0.6602 \mathrm{~m}$ dengan kedalaman gelombang pecah $\left(\mathrm{d}_{\mathrm{b}}\right)=0.692$ $\mathrm{m}$.

5. Ketinggian muka air rancangan $(\mathrm{DWL})=1.395 \mathrm{~m}$ yang dihitung dari MSL atau $\pm 0,00$.

6. Dimensi bangunan jetty:
a. Tinggi bangunan jetty $\left(\mathrm{El}_{\text {jetty }}\right)=3 \mathrm{~m}$

b. Berat batu lapis pertama $\left(\mathrm{W}_{1}\right)=2.486$ ton

c. Berat batu lapis kedua $\left(\mathrm{W}_{2}\right)$ $=0.2486$ ton.

d. Lebar puncak $(B)=2.434 \mathrm{~m}$

e. Tebal lapis pertama $\left(\mathrm{t}_{1}\right)=$ $2.434 \mathrm{~m}$

f. Tebal lapis kedua $\left(\mathrm{t}_{2}\right)=$ $1.129 \mathrm{~m}$

g. Tebal pelindung kaki $\left(\mathrm{t}_{\text {toe }}\right)=$ $1.781 \mathrm{~m}$

h. Lebar pelindung kaki $\left(\mathrm{B}_{\text {toe }}\right)$ $=2.166 \mathrm{~m}$

i. Berat batu pelindung kaki $\left(\mathrm{W}_{\text {toe }}\right)=0.148$ ton
7. Nilai $\mathrm{Ns}^{3}=50 \leq 300$ sehingga bangunan jetty dikatakan aman.

8. Perkiraan biaya pembangunan jetty di muara Sungai Sungga adalah Rp.4,106,578,000.00 (Empat Milyar Seratus Enam Juta Lima Ratus Tujuh Puluh Delapan Ribu Rupiah).

\subsection{Saran}

1. Perlu adanya update pengukuran detail sebelum pelaksanaan pembangunan jetty.

2. Perlu adanya survey quary material sebelum pelaksanaan pembangunan jetty.

\section{DAFTAR PUSTAKA}

Ardantha, I. M., Aryastana, P., Rahadiani, A. A. S. D., \& Candrayana, K. W. (2019). Analysis of Coastline Change in Klungkung Regency. The 1st Warmadewa Research and Development Seminar (WARDS), 19. Denpasar: EAI. https://doi.org/10.4108/eai.30-102018.2281487

Aryastana, P., Ardantha, I. M., \& Agustini, N. K. A. (2017). Analisis Perubahan Garis Pantai dan Laju Erosi di Kota Denpasar dan Kabupaten Badung dengan Citra Satelit SPOT. Jurnal Fondasi, 6(2), 100-111.

Aryastana, P., Ardantha, I. M., \& Candrayana, K. W. (2018). Coastline change analysis and erosion prediction using satellite images. MATEC Web of Conferences, 197, $1-5$. 
https://doi.org/10.1051/matecconf/20 1819713003

Aryastana, P., Ardantha, I. M., Nugraha, A. E., \& Candrayana, K. W. (2017). Coastline Changes Analysis in Buleleng Regency by Using Satellite Data. The 1st Warmadewa University International Conference on Architecture and Civil Engineering, 106-113. Denpasar: Warmadewa University Press.

Aryastana, P., Ardantha, I. M., \& Rahadiani, A. A. S. D. (2018). Pemanfaatan Citra Satelit SPOT dalam Analisis Perubahan Garis Pantai di Kabupaten Jembrana. Konferensi Nasional Teknik Sipil 12. Batam: Program Studi Teknik Sipil, Fakultas Teknik, Universitas Atmajaya Yogyakarta.

Aryastana, P., Ardantha, I. M., Rahadiani, A. A. S. D., \& Candrayana, K. W. (2018). Deteksi Perubahan Garis Pantai Di Kabupaten Karangasem Dengan Penginderaan Jauh. Jurnal Fondasi, 7(2), 94-104. https://doi.org/10.36055/jft.v7i2.407 9

Aryastana, P., Eryani, I. G. A. P., \& Candrayana, K. W. (2016). Perubahan garis pantai dengan citra satelit di Kabupaten Gianyar. PADURAKSA, 5(2), 70-81.

Azhikodan, G., \& Yokoyama, K. (2021). Erosion and sedimentation pattern of fine sediments and its physical characteristics in a macrotidal estuary. Science of The Total Environment, 753, 142025. https://doi.org/10.1016/j.scitotenv.20 20.142025

Cui, B.-L., \& Li, X.-Y. (2011). Coastline change of the Yellow River estuary and its response to the sediment and runoff

(1976-2005).
Geomorphology, 127(1-2), 32-40. https://doi.org/10.1016/j.geomorph.2 010.12 .001

Eulie, D. O., Corbett, D. R., \& Walsh, J. P. (2018). Shoreline erosion and decadal sediment accumulation in the Tar-Pamlico estuary, North Carolina, USA: A source-to-sink analysis. Estuarine, Coastal and Shelf Science, 202, 246-258. https://doi.org/10.1016/j.ecss.2017.1 0.011

Pattipawaej, O., Tanamal, K. T., Desiani, A., Dani, H. J., \& Pratama, A. R. (2013). Analisis Stabukutas Struktur Pelindung Pantai Baju Bronjong. Jurnal Teknik Sipil, 9(1), 38-56. https://doi.org/10.28932/jts.v9i1.136 8

Suryawan, I. N., Eryani, I. G. A. P., \& Rahadiani, A. A. S. D. (2019). Perencanaan Bangunan Jetty dari Bahan Bronjong pada Muara Tukad Melangit di Banjar Tegal Besar Kabupaten Klungkung. PADURAKSA, 8(1), 16-26.

Triatmodjo, B. (1999). Teknik Pantai. Yogyakarta: Beta Offset.

Werdi, N. M. K., \& Eryani, I. G. A. P. (2020). Alternatif Perencanaan Jetty di Muara Tukad Pangi Kabupaten Badung. PADURAKSA, 9(1), 102113.

https://doi.org/10.22225/pd.9.1.1678. 102-113

Yowono, N. (1992). Dasar-dasar Perencanaan Bangunan Pantai (Vol. 2). Yogyakarta: Laboratorium Hidraulika dan Hidrologi PAU-ITUGM. 